JOURNAL OF SECURITY AND SUSTAINABILITY ISSUES

ISSN 2029-7017 print/ISSN 2029-7025 online

2019 March Volume 8 Number 3

https://doi.org/10.9770/jssi.2019.8.3(14)

\title{
Scopus
}

\section{EVOLUTION OF CORPORATE SOCIAL RESPONSIBILITY APPLIED TO THE CONCEPT OF SUSTAINABLE DEVELOPMENT}

\author{
Maria Yevdokimova ${ }^{1}$, Victor Zamlynskyi ${ }^{2}$, Svetlana Minakova ${ }^{3}$, Olena Biriuk ${ }^{4}$, Olena Ilina ${ }^{5}$ \\ ${ }^{1}$ EM Strasbourg Business School University of Strasbourg, Strasbourg, France \\ ${ }^{2}$ Odessa National Politechnic University, Odessa, Ukraine \\ ${ }^{3}$ Institute of Market Problems and Economic \& Ecological Research, Odessa, Ukraine \\ ${ }^{4}$ Kyiv National Economic University named after Vadym Hetman, Kyiv, Ukraine \\ ${ }^{5}$ Kharkiv National Technical University of Agriculture P. Vasilenko, Kharkiv, Ukraine

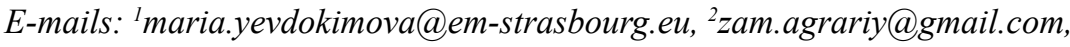

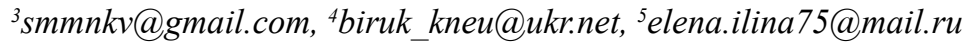

Received 13 February 2018; accepted 15 November 2018; published 30 March 2019

\begin{abstract}
This article is a continuation of the historical overview of corporate social responsibility (CSR), took place in the 20th century. The main definitions, principles, actions were explained with the purpose of research the influence if the kinds of responsibilities as legal, ethical, philanthropic on the sustainable development of the enterprise. The consequent CSR concepts observations are presented, namely Social Responsibility of Business Man, Stakeholder Approach, Three dimensional model, Three-dimensional model of principles, policies and processes, Institutional framework and extended corporate actions, Three-domains approach, Contemporary concept. The new XXI centuries SCR concepts were discovered and their theories fixed. Novel insights into contemporary meaning of SCR are being suggested.
\end{abstract}

Keywords: corporate social responsibility, ethics, sustainable development, sustainability, responsible behaviour, stakeholders

Reference to this paper should be made as follows: Yevdokimova, M.; Zamlynskyi, V.; Minakova, S.; Biriuk, O.; Ilina, O. 2019. Evolution of corporate social responsibility, Journal of Security and Sustainability Issues 8(3): 473-480. https://doi.org/10.9770/jssi.2019.8.3(14)

JEL Classifications: L22, L24, L25

\section{Introduction}

Concerns about corporate social responsibility have grown significantly during the last two decades. On a wide range of issues, corporations are encouraged to behave socially responsibly (Welford, \& Frost, 2006; Engle, 2006). Nevertheless, in both business and academic world there is no certainty as to the definition of CSR. Some state the following «We have looked for a definition and basically there isn't one». The main problem is rather that there are too many of such definitions, which are, as professor of Business Anthropology in University of Amsterdam Van Marrewijk concludes (2003), often biased toward specific interests and thus prevent the development and implementations of the concept. Not only has the issue become commonplace in the business press and among business and political leaders (Buhr \& Grafstro, 2004), but a body of academic literature has also emerged around it (Margolis \& Walsh, 2003). Nevertheless, little theoretical attention has been paid to understanding why or why not corporations act in socially responsible ways (Rowley \& Berman, 2001). Indeed, much of the literature on corporate social responsibility has been more descriptive or regulative than positivist in tone (Prahalad, \& Porter, 2003). Maignan and Ralston (2002) conceptualised corporate social responsibility as motivating principles (directed by values, stakeholders, performance); processes (programs and activities with the goal to implement the CSR principles and/ or handle specific stakeholder issues, including 
philanthropic, sponsorships, volunteer, code of ethics, quality, health and safety, and managing environmental impacts); and stakeholder issues (community, customer, employee, shareholders, suppliers). Corporate social responsibility (CSR) can be characterized as a beguiling field of research with «implications for academia, industry and society» (Okoye, 2009) which are worth attention. Despite the interest to the subject and broad academic discussion, there is still considerable absence of agreement regarding a correct or universal definition of CSR (Font et al, 2012). Even a cursory examination of foreign materials on CSR tends to suggest that there is a tendency to evolution of business behaviour and changes of paradigm. The existing literature also reminds us of the diversity of CSR in different countries, which should also be taken into consideration e.g. the Canadian (Montreal school of CSR), the Continental European and the Anglo-Saxon approaches to CSRS (Saether, Kim T.; Ruth V. Aguilera, 2008) have their individual specifics. These differences are known as a beliefs and cliches, some of examples are, for Chinese consumers, a socially responsible company makes safe, highquality products; for Germans it provides secure employment; in South Africa it makes a positive contribution to social needs such as health care and education (Knox, Simon, 2007). And even within Europe the discussion about CSR is very heterogeneous (Habisch et al., 2005). A more common approach to CSR is corporate philantrophy. This includes monetary donations and aid given to nonprofit organisations and communities. These donations could be made in areas such as the arts, education, housing, health, social welfare and the environment, among others, excluding political contributions and commercial event sponsorship (Tilcsik, A. \& Marquis, C., 2013).

\section{A historical overview of Corporate Social Responsibility definition}

The 21 st century brings attention to «stakeholder» diversity, whereas previously it was presented and used to describe stakeholders impacted by individual businesses. The beginning of this period was also marked by the appearance of the following theories: «sustainable development», «corporate citizenship», «corporate sustainability», corporate reputation», socially responsible investment» and «corporate social reporting» (Epstein, 2002). After the long-term evolution, Corporate Social Responsibility became an ethical and responsible path for business, thus CSR is a way of forming «higher and higher standards of living, whilst preserving the profitability of the corporation, for people both within and outside the corporation» (Hopkins, 2003). Hopkins (2004) narrated that CSR means the ethical behaviour of business towards its constituencies or stakeholders. However, there are a broad diversity of concepts and definitions describing the term «corporate social responsibility», but no general agreement of terms. Some companies prefer to use the terms «corporate citizenship», some «the ethical corporation», while others resort to such concept as «good corporate governance» or «corporate responsibility». These discrepancies cause some companies to consider CSR as clearly corporate philanthropy, others as a new corporate strategic structure, while others ignore the concept completely. Hopkins (2004) is of the opinion that using the term «corporate responsibility» (CR) instead of «corporate social responsibility» changes the nature of what the concept is all about. Many practitioners included the term «social» to encourage corporations to look at their social responsibilities as well as their usual «responsibilities». Hopkins (2004) further expressed that «Corporate Sustainability» is another parallel concept to CSR that has led to a lot of useful work on quantifying the issue of sustainability.

Technically, CSR is not a traditional management tool, thus it can be viewed as a moral duty rather than a business tactics (Gerard, \& Zwetsloot, 2003), which is reinforcing the need for clear guidance and a deeper understanding of social responsibility (Boeger, Murray, \& Villiers, 2008). A different suggestion is possible when CSR is broken down into manageable pieces and processes «CSR must be defined to contain a number of minimum requirements and to entail a system of corporate accountability through regulatory intervention and enforcement of obligations» (Boeger, Murray, \& Villiers, 2008).

According to the Commission of European Union (2001), the definition of CSR is a concept by which companies integrate social and environmental issues in their business transactions and in their cooperation with their stakeholders on a voluntary basis. Following an evaluation of the influence of current European CSR Policy, the Commission proposes a new definition of CSR: 
«The responsibility of enterprises for their impacts on society». The Communication then states that: "To fully meet their corporate social responsibility, enterprises should have in place a process to integrate social, environmental, ethical and human rights concerns into their business operations and core strategy in close collaboration with their stakeholders». Later in the Communication, the Commission stresses that «Enterprises must be given the flexibility to innovate and to develop an approach to CSR that is appropriate to their circumstances».

The balance between minimising risks through accountability and maximising opportunities through transparency and social innovation forms the basis of European Commission Enterprise 2020 initiative.

The United Nations Industrial Development Organisation defining Corporate Social Responsibility as a management concept by which companies integrate social and environmental concerns in their business operations and interactions with their stakeholders. CSR is generally understood as being the means through which a company attains a balance of economic, environmental and social essential actions («Triple-BottomLine-Approach»), while simultaneously dealing with the expectations of shareholders and stakeholders. In this respect it is vital to differentiate between CSR, which can be a strategic business management concept, and charity, sponsorships or philanthropy. Even though the latter can make it possible to contribute considerably to poverty reduction, will directly boost up the reputation of a company and promote its brand, the concept of CSR is definitely over and above that (UN IDOC web page).

The World Business Council for Sustainable Development emphasized that CRS is the continuing responsibility by businesses to act ethically and enable economic development while making the quality of life, workforce and families better as well as the local community and society in general. Fundamentally, Corporate Social Responsibility must also have common actions. These actions are the following:

- Environmental sustainability: recycling, waste management, water management, renewable energy, reusable materials, 'greener' supply chains, reducing paper use and adopting Leadership in Energy and Environmental Design (LEED) building standards (Matthews, 2012; Štreimikienė et al., 2016; Simionescu et al., 2017);

- Community involvement: it may mean attracting funds for local charities, providing volunteers, financing local events, making use of local workers, assisting local economic development, joining in fair trade practices, etc. (Hammers, 2003; Blanco-Encomienda \& Ruiz-García, 2017; Bilan et. al., 2017);

- Ethical marketing: companies that ethically market to consumers are putting a higher value on their clients and respecting them as people who are ends in themselves. They do not attempt to manipulate or impose their false advertisement on potential consumers. This is essential for companies that want to be regarded as ethical (McWilliams, \& Siegel, 2001 Danaj et al., 2018).

According to M. Scilly, an American writer and editor who writes for various online publications (for example, Houston chronicle journal) specialising in business and management, the four types of CSR are as follows:

The economic responsibility is primarily concerned with profit. So the simple fact is that if an enterprise does not render a profit, it will not stay long in business, employees will be put out of work and the company will not even be able to bear its social obligations at all. Before a company intends being a good corporate citizen, it is necessary to make certain that it can first of all bring profit.

The legal responsibility is the obligations that are put on it by the legislation. Next to ensuring that a company is profitable, and obeys all laws, it is the most important aspect in accordance with the theory of corporate social responsibility. Legal responsibilities can vary from securities regulations to labor law, environmental law and so much as criminal law. 
The ethical responsibility of a company considers its employees, customers and society as a whole. Ethical responsibilities are imposed on the company by itself, due to the fact that its proprietors consider it the right decision and not because they have any commitment to act like this. Ethical responsibilities may involve being environmentally friendly, paying decent salaries or refusing to deal with autocratic regimes.

The philanthropic responsibility should exceed what is simply required or what the company considers right. It involves making an effort to help the society, for instance, by providing free services to organisations in local community, involving in projects to protect the environment or making contribution to charitable causes. To summarise this part we present the development of CSR concept in a following table:

Table: Evaluation of Corporate Social Responsibility concept since 1950s-2000s

\begin{tabular}{|c|c|c|c|}
\hline Period & Name of concept & Description & Literature \\
\hline \multirow{3}{*}{ 1950s } & \multirow{3}{*}{$\begin{array}{l}\text { Social Responsibility } \\
\text { of Business Man }\end{array}$} & $\begin{array}{l}\text { The obligations of businessmen to conduct policies, to make decisions or to act } \\
\text { in such ways that are desirable according to the goals and values of society. }\end{array}$ & $\begin{array}{l}\text { Bowen } \\
(1953)\end{array}$ \\
\hline & & $\begin{array}{l}\text { Some socially responsible business decisions can be accounted for by the long- } \\
\text { term economic profit of the firm, paying back accordingly for its socially respon- } \\
\text { sible behavior. }\end{array}$ & $\begin{array}{l}\text { Davis } \\
(1960)\end{array}$ \\
\hline & & $\begin{array}{l}\text { Private contribution to society's economic and human resources and a wish from } \\
\text { the side of business to see that those resources were used for a wide range of } \\
\text { social projects. }\end{array}$ & $\begin{array}{l}\text { Frederick } \\
\quad(1960)\end{array}$ \\
\hline \multirow[b]{2}{*}{$\begin{array}{l}\text { 1960s- } \\
\text { 1970s }\end{array}$} & $\begin{array}{l}\text { Stakeholder } \\
\text { Approach }\end{array}$ & $\begin{array}{l}\text { Instead of aiming exceptionally at larger profits to its shareholders, a responsible } \\
\text { company takes into consideration the interests of employees, suppliers, dealers, } \\
\text { local communities and the nation as a whole. }\end{array}$ & $\begin{array}{l}\text { Johnson } \\
(1971)\end{array}$ \\
\hline & $\begin{array}{l}\text { Three dimensional } \\
\text { model }\end{array}$ & $\begin{array}{l}\text { Three dimensional model The concept contains corporate responsibilities (i.e., } \\
\text { economic, legal, ethical and philanthropic), social aspects of business (labour } \\
\text { standards, human rights, environment protection and anticorruption) and cor- } \\
\text { porate actions (reactive, defensive, accommodative and proactive). }\end{array}$ & $\begin{array}{l}\text { Carroll } \\
(1979)\end{array}$ \\
\hline \multirow[b]{2}{*}{$\begin{array}{l}\text { 1980s- } \\
\text { 1990s }\end{array}$} & $\begin{array}{l}\text { Three-dimensional } \\
\text { model of principles, } \\
\text { policies and processes }\end{array}$ & $\begin{array}{l}\text { Adaptation of the principles of corporate responsibility, the policies of social } \\
\text { issue management and the process of action to a developing system. }\end{array}$ & $\begin{array}{c}\text { Wartick and } \\
\text { Cochran } \\
(1985)\end{array}$ \\
\hline & $\begin{array}{l}\text { Institutional framework } \\
\text { and extended corporate } \\
\text { actions }\end{array}$ & $\begin{array}{l}\text { Established frame-work and extended corporate actions Four types of corporate } \\
\text { responsibilities (i.e., economic, legal, ethical and philanthropic) were connect- } \\
\text { ed to three basic levels (legal, organisational and individual), while corporate } \\
\text { actions are extended to assessment, stockholder management and implementa- } \\
\text { tion management. }\end{array}$ & $\begin{array}{l}\text { Wood } \\
(1991)\end{array}$ \\
\hline \multirow{2}{*}{$2000 s$} & $\begin{array}{l}\text { Three-domains } \\
\text { approach }\end{array}$ & Three aspects of corporate responsibilities: economic, legal and ethical. & $\begin{array}{l}\text { Schwartz, } \\
\text { Carroll } \\
(2003) \\
\end{array}$ \\
\hline & $\begin{array}{l}\text { Contemporary } \\
\text { concept }\end{array}$ & $\begin{array}{l}\text { A process to bring together social, environmental, ethical, human rights and con- } \\
\text { sumer issues into business operations and basic strategy in close association } \\
\text { with the stakeholders. }\end{array}$ & $\begin{array}{l}\text { European } \\
\text { Commission } \\
(2001)\end{array}$ \\
\hline
\end{tabular}

\section{Evolution of Corporate Social Responsibility (CSR) to the New Concepts}

The field of corporate social responsibility (CSR) has notably increased and today includes an abundance of theories, approaches, and terminologies. Furthermore, some theories combine different approaches and use the same terminology with different meanings (Garriga, \& Melé, 2004). The following theories: «sustainable development», «corporate citizenship», «corporate sustainability», «corporate reputation», «socially responsible investment» and «corporate social reporting» (Epstein, 2002). Until now, it has no generally accepted common framework, however, most agree that one of its main characteristics undertaking a commitment with society. In order to facilitate its incorporation, a largely voluntary corporate responsibility infrastructure has been created, including, among others: business principles; business-related standard setting; accreditation and certification organisations; corporate responsibility consulting organisations; business membership organisations with sustainability and responsibility orientation; industry-specific initiatives; business-related corporate responsibility institutions; and stock indexes with responsibility orientation (Waddock, 2008; Balcerzak \& Pietrzak, 2016; Karnitis \& Karnitis, 2017; Peterlin et al., 2018; Tvaronavičienè et al., 2018; Aktan et al., 
2018; Razminienè, Tvaronavičienè, 2018; Melas et al., 2017; Hasanudin et al., 2018; Kita, Šimberová, 2018; Smaliukiene, R.; Monni, S, 2019).

Several scholars have offered a number of classifications of the concept. Frederick $(1987,1998)$ presents the evolution of CSR based on a conceptual transition and classifies it in to four chronological phases:

\begin{tabular}{|c|c|}
\hline CSR & I. philanthropic and voluntarily assumed approach; \\
\hline CSR & $\begin{array}{r}\text { II. + III. company could be recognised by the quality of its corporate culture and the normative society } \\
\text { that embodies universal human rights principles vital to society, while granting economic enterprises the degree } \\
\text { of flexibility and practicality needed for successful market operations; }\end{array}$ \\
\hline CSR & IV. truly corporate global citizens. \\
\hline
\end{tabular}

For their part, Garriga and Melé (2004) present a classification that considers each theory from the viewpoint of how cooperation phenomena between business and society are highlighted:

\begin{tabular}{|c|c|}
\hline Instrumental theories & concentrating on achieving economic goals through social activities \\
\hline Political theories & concentrating on a responsible use of business power in the political arena \\
\hline Integrative theories & concentrating on the integration of social needs \\
\hline Ethical theories & concentrating on the right means to attain a good society \\
\hline
\end{tabular}

Over six decades the field of CSR has developed several approaches, each within its own theoretical framework. Which theory is the best? It depends on what you are looking for, states Melé (2008), In Figure 2 Melé (2008) presents chronology of the various theories and approaches to CSR with historical account.

Figure 2. Corporate social responsibility (CSR): theories and approaches Melé (2008)

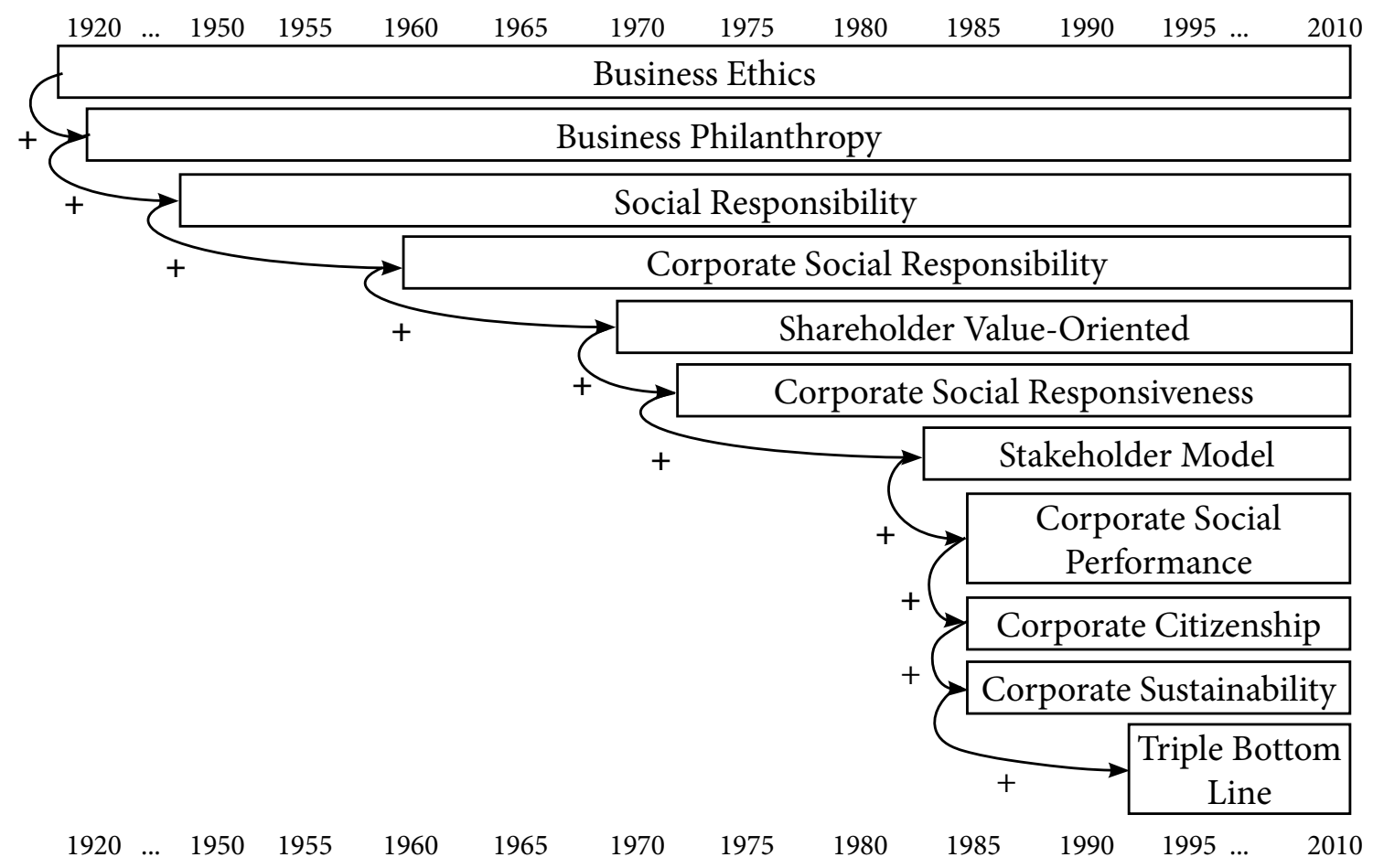

The following table present a short genesis of the Concept of Corporate Social Responsibility. 
Table 2. The Genesis of the C oncept of Corporate Social Responsibility (Madrakhimova, 2013)

\begin{tabular}{|c|c|c|}
\hline The name of the concept & Authors & Basics \\
\hline $\begin{array}{c}\text { Corporate Social } \\
\text { Responsibility }\end{array}$ & $\begin{array}{c}\text { Bowen, 1953 } \\
\text { Davis, 1960 } \\
\text { Carroll, 1979 }\end{array}$ & $\begin{array}{c}\text { Ordered content of CSR, systematic } \\
\text { level of normative }\end{array}$ \\
\hline $\begin{array}{c}\text { Corporate Social } \\
\text { Responsiveness }\end{array}$ & $\begin{array}{c}\text { Ackerman, 1973 } \\
\text { Preston, Post, 1975 } \\
\text { Frederick, 1978 } \\
\text { Carroll, 1979 }\end{array}$ & $\begin{array}{c}\text { Corporate social susceptibility, the capabilities } \\
\text { of cor-porations to take social action }\end{array}$ \\
\hline $\begin{array}{c}\text { Corporate social } \\
\text { performance }\end{array}$ & Wood, 1991 & A model of corporate social performance \\
\hline $\begin{array}{c}\text { Corporate social performance } \\
\text { Management (concept) } \\
\text { stakeholders }\end{array}$ & $\begin{array}{c}\text { Freeman, 1984 } \\
\text { Clarkson, 1988 } \\
\text { Donaldson, Preston, 1995 } \\
\text { Post, Preston and Sachs, 2002 }\end{array}$ & $\begin{array}{c}\text { Give a new definition of the corporation disclosed } \\
\text { its relationship with stakeholders }\end{array}$ \\
\hline Corporate Citizenship & Longsdon Wood, 2002 & A model formed of corporations in relation to its stake-holders \\
\hline Corporate & Van Marreviyk, 2003 \\
Sustainability & Steuer, 2005 & $\begin{array}{c}\text { The relation between social responsibility and corporate } \\
\text { social problems of stability with agency problems }\end{array}$ \\
\hline
\end{tabular}

The curved arrows and the plus signs are intended to emphasise that the emergence of every new theory and approach has contributed to the enrichment of CSR and the awareness and comprehension of the issue. An impressive history associated with the development of the concept and description of corporate social responsibility brought alternative themes and thematic framework.

\section{Conclusions}

This is the first and most widely accepted world standards for sustainability reporting. It allows businesses and governments all over the world to understand and convey their influence on essential sustainability problems such as climate change, human rights, governance and social well-being which promotes to establish social, environmental and economic advantages for everybody. The GRI Sustainability Reporting Standards are elaborated with multi-stakeholder contributions and based in the public interest. The practice of making sustainability information public stimulates liability, contributes to identifying and managing risks, and promotes organisations to take advantage of new opportunities. Corporate Social Responsibility in a contemporary understanding is a pillar of Corporate Sustainability. It could regarded as the corporate response to sustainable development represented by strategies and practices that address the key issues for the world's sustainable development.

\section{References}

Aktan, B., Turen, S., Tvaronaviciene, M., Celik, S., Alsadeh, H.A. (2018). Corporate governance and performance of the financial firms in Bahrain. Polish Journal of Management Studies, 17(1), 39-58. https://doi.org/10.17512/pjms.2018.17.1.04

Balcerzak, A. P., Pietrzak, M. B. (2016), Quality of Institutions for Knowledge based Economy within New Institutional Economics Framework. Multiple Criteria Decision Analysis for European Countries in the Years 2000-2013, Economics and Sociology, 9(4), 66-81. https://doi.org/10.14254/2071-789X.2016/9-4/4

Bilan, Y., Mishchuk, H., Pylypchuk, R. 2017. Towards sustainable economic development via social entrepreneurship, Journal of Security and Sustainability Issues 6(4), 691-702. http://doi.org/10.9770/jssi.2017.6.4(13)

Blanco-Encomienda, F. J., Ruiz-García, A. (2017). Evaluating the Sustainability of the Spanish Social Security System. Economics and Sociology, 10(4), 11-20. https://doi.org/10.14254/2071-789X.2017/10-4/1

Boeger, N., Murray, R., \& Villiers, C. (2008). Perspectives on Corporate Social Responsibility: Corporations, globalisation, and the law. Edward Elgar Publishing Limited.

Boeger, N., Murray, R., \& Villiers, C. (2008). Perspectives on Corporate Social Responsibility: Corporations, globalisation, and the law. Edward Elgar Publishing Limited.

Bowen, H.R. (1953). Social responsibilities of the businessman. New York: Harper \& Row. 
Buhr, H., \& Grafstrom, M. (2004). Corporate social responsibility. Paper presented at the conference on Corporate Social Responsibility in the Era of the Transforming Welfare Satate, Florencia, Italia.

Carroll, A.B. (1979). A Three-Dimensional Conceptual Model of Corporate Performance. Academy of Management Review, 4, 497-505.

Danaj, A., Lazányi, K., \& Bilan, S. (2018). Euroscepticism and populism in Hungary: The analysis of the prime minister's discourse. Journal of International Studies, 11(1), 240-247. https://doi.org/10.14254/2071-8330.2018/11-1/18

Davis, K. (1960). Can business afford to ignore social responsibilities? California Management Review, 2, 70-76.

Engle, R.L. (2006). Corporate social responsibility in host countries: a perspective from American managers. Corporate Social Responsibility and Environmental Management, 14, 16-27.

Epstein, E. (2002). Business ethics as an academic discipline: the past, present and future (analysis of the American experience). Herald of St.Petersburg Unt. Ser. Management, 3, 27.

European Commission. (2001). European Commission Strategy on CSR. Retrieved from http://ec.europa.eu/growth/industry/corporatesocial-responsibility_en

Font, X., Walmsley, A., Cogotti, S., McCombes, L., \& Häusler, N. (2012). Corporate Social Responsibility: The Disclosure-Performance Gap. Tourism Management, 33, 1544-1553.

Frederick, W.C. (1960). The growing concern over business responsibility. California Management Review, 2, 54-61.

Frederick, W.C. (1987). Theories of Corporate Social Performance, in S. P. Sethi and C. M. Flabe (ed.), Business and Society: Dimensions of Conflict and Cooperation (Lexington Books, New York), 142-161.

Frederick, W.C. (1998). Moving to CSR. Business and Society, 37, 40-60.

Garriga, E., \& Mele, D. (2004). Corporate social responsibility theories: Mapping the territory. Journal of Business Ethics, 53, 51-71.

Gerard, I., \& Zwetsloot, J. (2003). From Management Systems to Corporate Social Responsibility. Journal of Business Ethics, 44, 201-208.

Hammers, M. (2003, October 3). Starbucks is Pleasing Employees and Pouring Profits. Workforce Management, 58-59.

Hammers, M. (2003, October 3). Starbucks is Pleasing Employees and Pouring Profits. Workforce Management, 58-59.

Hasanudin, A.I.; Yuliansyah, Y.; Said, J.; Susilowati, Ch.; Muafi. 2019. Management control system, corporate social responsibility, and firm performance. Entrepreneurship and Sustainability Issues, 6(3), 1154-1168. http://doi.org/10.9770/jesi.2019.6.3(21)

Hopkins, M. (2003). The Planetary Bargain - CSR Matters. Earthscan: London.

Hopkins, M. (2004). Corporate Social Responsibility: An Issues Paper. International Labour Office Working Paper, 27, 1-41.

Johnson, H.L. (1971). Business in contemporary society: Framework and issues. Belmont, CA: Wadsworth.

Karnitis, G., \& Karnitis, E. (2017). Sustainable growth of EU economies and Baltic context: Characteristics and modelling. Journal of International Studies, 10(1), 209-224. https://doi.org/10.14254/2071-8330.2017/10-1/15

Kita, P.; Šimberová, I. (2018). An overview of business models in the Czech chemical industry: a sustainable multiple value creation perspective, Entrepreneurship and Sustainability Issues 6(2), 662-676. http://doi.org/10.9770/jesi.2018.6.2(14)

Maignan, I., \& Ralston, D. (2002). Corporate Social Responsibility in Europe and the U.S.: Insights from Businesses' Self-Presentations. Journal of International Business Studies, 33, 497-514.

Margolis, J.D., \& Walsh, J.P. (2003). Misery loves companies: Rethinking social initiatives by business. Administrative Science Quarterly, 8, 268-305.

Matthews, R. (2012). Top Business Sustainability Trends for 2012. The Green Market Oracle. Retrieved from http://www. thegreenmarketoracle.com/2012/01/top-business-sustainability-trends-for.html\#more.

McWilliams, A., \& Siegel, D. (2001). Corporate social responsibility: A theory of the firm perspective. Academy of Management Review, 26, 117-127. 
Melas, V.; Lisin, E.; Tvaronavičienè, M.; Peresadko, G.; Radwański, R. 2017. Energy security and economic development: renewables and the integration of energy systems. Journal of Security and Sustainability Issues, 7(1), 133-139. https://doi.org/10.9770/jssi.2017.7.1(11)

Mele, D. (2008). Corporate social responsibility theories. In A. Crane, A. McWilliams, D. Matten, J. Moon, \& D. Siegel (Eds.). The Oxford handbook of corporate social responsibility. Oxford University Press, 47-82.

Okoye, A. (2009). Theorising Corporate Social Responsibility as an Essentially Contested Concept: Is a Definition Necessary? Journal of Business Ethics, 89, 613-627.

Peterlin, J.,Dimovski, V., Tvaronavičienė, M., Grah, B., Kaklauskas, A. (2018). The strategic process of developing social aspects of sustainability through the vision reflection in business education. Technological and Economic Development of Economy, 4(4), 1718-1736. https://doi.org/10.3846/tede.2018.5198

Prahalad, C.K., \& Porter, M. (2003). Harvard Business Review on Corporate Responsibility. Harvard Business School Press.

Razminienė, K.; Tvaronavičienė, M. 2018. Detecting the linkages between clusters and circular economy, Terra Economicus, 16(4): 50-65 https://doi.org/10.23683/2073-6606-2018-16-4-50-65

Rowley, T., \& Berman, S. (2001). A Brand New Brand of Corporate Social Performance. Business and Society, 39, $397-418$.

Schwartz, M.S., \& Carroll, A.B. (2003). Corporate social responsibility: a three domain approach. Business Ethics Quarterly, 13, 503-530.

Simionescu, M., Albu, L. L., Raileanu Szeles, M., \& Bilan, Y. (2017). The impact of biofuels utilisation in transport on the sustainable development in the European Union. Technological and Economic Development of Economy, 23(4), 667-686.

Smaliukiene, R.; Monni, S. (2019). A step-by-step approach to social marketing in energy transition. Insights into Regional Development, 1(1), 19-32. http://doi.org/10.9770/IRD.2019.1.1(2)

Štreimikienė, D., Strielkowski, W., Bilan, Y., \& Mikalauskas, I. (2016). Energy dependency and sustainable regional development in the Baltic States: A review. Geographica Pannonica, 20(2), 79-87.

Tvaronavičienė, M., Prakapienė, D., Garškaitė-Milvydienė, K., Prakapas, R., Nawrot, Ł. (2018). Energy Efficiency in the Long-Run in the Selected European Countries. Economics and Sociology, 11(1), 245-254. https://doi.org/10.14254/2071- 789X.2018/11-1/16

Van Marrewijk, M. (2003). Concepts and definitions of CSR and corporate sustainability: between agency and communion. Journal of Business Ethics, 44, 95-105.

Waddock, S. (2008). The Difference Makers: How Social and Institutional Entrepreneurs Created the Corporate Responsibility Movement. Greenleaf Publishing, Sheffield.

Wartick, S.L., \& Cochran, P.L. (1985). The Evolution of the Corporate Social Performance Model. Academy of Management Review, $10,758-769$.

Welford, R., \& Frost, S. (2006). Corporate social responsibility in Asian supply chains. Corporate Social Responsibility and Environmental Management, 13, 166-176.

Wood, D.J. (1991). Corporate Social Performance Revisited. Academy of Management Review, 16, 691-718. 